\title{
A review on Notarial Deed Restriction Regulation based on Law on Office of Notary Public
}

\author{
Calvin Oktaviano Adinugraha*; Albertus Sentot Sudarwanto; Novendri Amiruddin \\ Faculty of Law, Universitas Sebelas Maret, Indonesia \\ Email: oktavius30@yahoo.com
}

http://dx.doi.org/10.18415/ijmmu.v5i2.380

\begin{abstract}
The present study aimed to review the Regulation of Central Honorary Council of Indonesian Notary Association no. 1of 2017 regarding Fairness Limit of Number of Permanent Deed (Per.DKP No. 1/2017) from the perspective of Law on Office of Notary Public. This study was classified as normative juridical legal study and was implemented by using statute approach. The legal material used for this study were books, journals, and the findings of the previous study that are supported by the interviews to the Notary Honorary Council. The data collection was done through literature study and interviews. The data were analyzed by using deductive reasoning. The finding of the study and discussion found that Per.DKP No.1/2017 that restricting notary' authority contradicts against notary' obligation to accommodate the parties' concern as it is stated in the law of Office of Notary Public. Besides, the sanction imposed for the violation against this regulation is limited only in becoming the object of investigation of Notary Honorary Council.
\end{abstract}

Keywords: Authority; Restriction; Notary

\section{Introduction}

A contract is one of the community' needs in interacting between one and others in term of civil law relationship ${ }^{1}$ and because of that, the state provides a facilitator to accommodate legal activity committed by one legal subject with other legal subjects by appointing such authority to the function of Notary public. The existence of Notary' function holds an essential role to make an authentic written item of evidence for legal activity done by the community. ${ }^{2}$ In performing their duty and authority, Notary public adheres law no. 2 of 2014 on the amendment of Law no. 30 of 2004 regarding the office of Notary (UUJN) as well as the last Notary code of ethics is changed by the Change of Notary' code of ethics of Indonesian Notary Association Extraordinary Congress in Banten, 29-30 May 2015.

The rapid economic advancement requires a notary to take a role in a legal activity done by the community. One of community' activities that seize Indonesian Notary Association' concern is fiduciary

${ }^{1}$ Habib Adjie. (2014). Merajut Pemikiran dalam Dunia Notaris dan PPAT, PT Citra Aditya Bakti, Bandung, p. 66.

${ }^{2}$ Hartanti Sulihandari and Nisya Rifiani. (2013). Prinsip-Prinsip Dasar Profesi Notaris, Dunia Cerdas, Jakarta, p. 3. 
deed. This is caused by increasing easiness to purchase a motor vehicle by using financing institution facility which implies on the request of fiduciary deed making. Consequently, it makes notary make hundreds of deeds every day. ${ }^{3}$

Based on this phenomenon, on 28 February 2017, the Central Honorary Council as one of the instruments of Indonesian Notary Association (INI) issued the Regulation of Central Honorary Council of Indonesian Notary Association no. 1 of 2017 regarding the Fairness Limit of Number of Permanent Deed (Per.DKP no.1/2017). ${ }^{4}$ The issuance of Per.DKP no.1/2017 brings various notary' pros and cons. ${ }^{5}$

This regulation is the result of the recommendation of Broadened Plenary Meeting of Indonesian Notary Association (I.N.I) in Solo in October 2014 which is then expressed in Indonesian Notary Association Extraordinary Congress in Tangerang on 28-30 May 2015. This restriction proposal is calculated based on the average daily work hours without break time and others activity, and then is divided by 20 deeds by assumption of 24 minutes for each deed. ${ }^{6}$ This regulation is stated explicitly in article 2 paragraph (1) of Per.DKP no.1/2017 that the Fairness Limit of deed making by Notary as the member of Association is 20 (twenty) deeds per day, it is the elucidation of article 3 number 18 of The Change of Notary' code of ethics of Indonesian Notary Association Extraordinary Congress in Banten, 29-30 May 2015 which states that: "A notary shall make deeds in the fairness limit to implement the regulatory legislation, especially the law on office of Notary and code of ethics."

Furthermore, in article 2 paragraph (2) of Per.DKP No.1/2017 determine that "If a Notary will make more than 20 (twenty) deeds in a sequence of legal activity that requires interrelated deed, and/ or other deeds, as long as it is accountable which is done in accordance with UUJN, the procedure of notarial' deed making, Notary' code of ethics (KEN), appropriateness and feasibility as well as other regulatory legislation." Viewed from the content of article 2 paragraph (1) and (2) of Regulation of Central Honorary Council of Indonesian Notary Association no. 1 of 2017 above, these two regulations have not reflected legal certainty that exhibits tolerance of fairness limit in a particular condition. Thus, there is an inconsistency in article 2 of Per.DKP No.1/2017, and it reviewed further in this study.

\section{Methodology}

This legal study employed juridical normative study method, it is a legal study conducted by using secondary data so it may be called a literature study. The juridical normative study involves studies of law principles, law systematics, vertical and horizontal synchronization level, law comparison, and law history. This juridical normative study was supported by interviews with several sources. ${ }^{7}$ The approach used in this study was statute approach. Statute approach was done by studying all laws and regulations related to the legal issue being discussed. ${ }^{8}$ This approach allows the researcher to study the consistency and coherence between a law with other laws, or between laws and the Constitution, or between regulations and laws.

The primary legal material used in this study consist of legislation. While, the secondary legal material comprised books, literature, interviews, studies' findings, and legal journals relevant to the topic of the current study. The researcher employed a deductive method to analyze the legal material. This deductive method is started by proposing major premise and then is followed by the minor premise. In the

\footnotetext{
${ }^{3}$ http://medianotaris.com/pembatasan_akta_adalah_ranah_uu_berita477.html, accessed on Wednesday, 14 June 2017 at 12:23 WIB.

${ }^{4} \mathrm{http}: / /$ ini.id/artikel-content.php?id=1, accessed on Wednesday, 14 June 2017 at 12:15 PM WIB.

${ }^{5}$ Tavip Suganjar, (2017), in Renvoi magazine number: 3.171.XV Agustus 2017, page. 14.

${ }^{6} \mathrm{http} / / /$ medianotaris.com/pembatasan_akta_adalah_ranah_uu_berita477.html, accessed on Wednesday, 14 June 2017 at 12:23 WIB.

${ }^{7}$ Soerjono Soekanto and Sri Mamudji, (2007), Penelitian Hukum Normatif, Suatu Tinjauan Singkat, Raja Grafindo Persada, Jakarta, p. 13-14.

${ }^{8}$ Peter Mahmud Marzuki, (2014), Penelitian Hukum: Edisi Revisi, Prenada Media Grup, Jakarta, p. 133.
} 
current study, the data were analyzed based on the findings of the studies, by analyzing supporting data from literature studies and regulatory legislation regarding the current study.

\section{Discussion A Review on the Notarial Deed Restriction Regulation based on the Law on Office of Notary}

UUJN provides notary to forgather in a Notary Organization known as Indonesian Notary Association (INI), it is the only free and independent association of profession for Notary which aim is to enhance the quality of Notary' profession, as it is stated in article 82 of UUJN. Also, article 83 paragraph (1) of UUJN regulates that Notary organization stipulates and enforces Notary' code of ethics.

INI states that code of ethics is all moral principles determined by INI which is in force for all members or other people who hold and perform notarial office either in office implementation or daily life. ${ }^{9}$ Notary' code of ethics contains the material element of obligation, prohibition, exception, and sanction for a notary if he/she is proven to violate the code of ethics. In addition, Notary' code of ethics also regulates the procedure of code of ethics enforcement and temporary suspension as the member of INI. Notary' professional ethic emerges for two following reasons: ${ }^{10}$

1. Professional ethics acts as a mechanism done by an organization to control its member behavior and then is to correct it if their behavior is considered less ethical.

2. Professional ethics acts as the relationship alignment between colleagues.

Article 83 paragraph (1) of UUJN does not only order INI organization to stipulate code of ethics but also to enforce it. Based on the order of that Law, INI establishes Honorary Council to enforce INI' Ethical Code. Notary' Code of Ethics is a moral principle determined by Indonesian Notary Association based on the decision of Congress and/or determined and regulated within the regulatory legislation that regulates it and is in force for all members and all people who perform the duty and the office of Notary.

Article 4 number 16 of Indonesian Notary Association Code of Ethics determines that " a Notary or other people (as long as that individual perform the office of Notary) is forbidden to make a deed more than the fairness limit which the amount is determined by the Honorary Council." In addition, article 3 number 18 of Indonesian Notary Association Code of Ethics states that "Notary or other people (as long as that individual performs the office of Notary) shall make deed within the amount of fairness limit to implement the regulatory legislation, especially the Law on Office of Notary and Code of Ethics." This matter becomes the reason for the emergence of Regulation of Central Honorary Council of Indonesian Notary Association no. 1of 2017 regarding Fairness Limit of Number of Permanent Deed (Per.DKP No.1/2017). In addition, the daily fairness limit regulated in Per.DKP No.1/2017 is based on the notary' obligation in term of reading the deed which is often not performed by the Notary. ${ }^{11}$ According to Habib Adjie, number 20 (twenty) in Per.DKP has created perturbation among the Notary, especially the Notary who usually makes Deed of Fiduciary Guarantee and deeds related to Housing Loan (KPR) more than twenty deeds, even reach 100 deeds for one agreement. ${ }^{12}$

\footnotetext{
${ }^{9}$ Maharani Kumalasari and Moch. Najib Imanullah. (2018). Efektivitas Peraturan Dewan Kehormatan Pusat Ikatan Notaris Indonesia Nomor 1 Tahun 2017 tentang Batas Kewajaran Jumlah Pembuatan Akta Perhari Di Surakarta, Jurnal Repertorium, Volume 5, Nomor 1, p. 164.

${ }^{10}$ Anke Dwi Saputro, (2008), Jati Diri Notaris Indonesia Dulu, Sekarang dan Di Masa Datang: 100 Tahun Ikatan Notaris Indonesia, PT Gramedia Pustaka, Jakarta, p. 196.

${ }^{11}$ The result of the interview with Sugiarto as the Notary Regional Supervisory Council of Central Java on 23 February 2018.

${ }^{12} \mathrm{http} / / / \mathrm{www}$.indonesianotarycommunity.com/per-dkp-nomor-12017-tidak-membatasi-kewenangan-notaris/, accessed on Tuesday, 29 May 2018 , at 15:39 WIB.
} 
However, it is important to note that UUJN does not regulate the restriction of deed making in a day. According to the writer, it cannot be justified since the formulation of the regulation shall refer to Law no.12 of 2011 about The Formulation of Regulatory Legislation.

Law number 12 of 2011 is the legal foundation for the formulation of regulatory legislation either in central or regional level. This law is formulated to create regulatory legislation formulation orderliness, to make steady, round and harmonious, not overlapping, and not contradictory norm formulation and conception. Through that law, all institutions who are authorized to formulate regulatory legislation are expected to hold standardized specific process and method guideline in formulating systematic, integrative, and deliberate regulatory legislation. So in this matter, the concept of a regulation formulation shall be in accordance with the regulatory legislation formulation principles determined by the law. ${ }^{13}$

There are some principles held in formulating and implementing regulatory legislation: ${ }^{14}$

1. a higher-level rule abrogates lower ones, or the principle of lex superior derogat legi inferiori, if a conflict occurs between a higher and lower regulatory legislation, the higher ones shall be prioritized.

2. A later law repeals an earlier law, or the principle of Lex posterior derogat legi prior, It is a principle of legal interpretation where the later law or posterior overrule the earlier law or prior. This principle is usually used in either national or international law.

3. The principle of Lex specialis derogat legi generali, it is a legal principle which states that Special law or lex specialis repeals general laws or lex generalis;

In addition to the principle above, the formulation of the regulation shall hold the principles of good regulatory legislation formulation as it is stated in article 5 of law no. 12 of 2011 about the Formulation of Regulatory Legislation.

1. Purpose Intelligibility Principle, this principle accounts that every formulation of regulatory legislation shall possess intelligible purpose to be obtained.

2. Institutional principle or proper maker official, this principle explains that every type of regulatory legislation shall be made by the authorized state institution or regulatory legislation maker official, such regulatory legislation can be annulled or void as matter of law if it is made by the unauthorized ones.

3. Compliance principle among the types, hierarchy, and content, this principle asserts that regulatory legislation formulation shall pay attention to the proper content that is suitable with the types and the hierarchy of the regulatory legislation.

4. Applicability principle, this principle means that every regulatory legislation formulation shall consider its effectiveness among the society either philosophical, sociological, or juridical;

5. Efficiency and Effectiveness Principle, this principle means that every regulatory legislation is made because it is necessary and is useful in regulating the life of people and of the nation;

6. Formulation Intelligibility principle, this principle means that every regulatory legislation shall meet technical requirement of regulatory legislation formulation, systematics, words or term choice, and

\footnotetext{
${ }^{13}$ Ferry Irawan Febriansyah. (2016). Konsep Pembentukan Peraturan Perundang-undangan di Indonesia, Jurnal Perspektif, Volume XXI, Nomor 3, Edisi September, p. 226.

${ }^{14}$ Ibid.,page. 226-227.
} 
clear and understandable legal language so it does not lead to various interpretation during its implementation;

7. Openness Principle, this principle means that in regulatory legislation formulation started from planning, arranging, discussing, stipulating, and enacting stage shall be transparent and overt. Therefore, all member of the society holds vast opportunities to express their suggestion during regulatory legislation formulation.

The hierarchy regulated in article 7 of law no. 12 of 2011 about the formulation of regulatory legislation state that the types and hierarchy of regulatory legislation consist of:

1. The 1945 Constitution;

2. Decree of People Consultative Assembly;

3. Law/ Government Regulation in Lieu of Law;

4. Governmental Regulation;

5. Presidential Regulation;

6. Provincial Regulation; and

7. Regional/ municipal regulation.

Based on the types and hierarchy of legislation above, Per.DKP No.1/2017 is categorized as regulatory legislation as it is stated in article 8 of Law no.12 of 2011 about the formulation of Regulatory legislation.

(1) The type of Regulatory legislation other than those meant in article 7 paragraph (1) covers the regulation stipulated by People Consultative Assembly, House of Representatives, Regional House of Representatives, Supreme Court, Constitutional Court, Finance Auditor Body, Judicial Commission, Bank Indonesia, Minister, body, institution, or equal commission formed by the Law or the Government upon instruction of Law, Provincial Regional House of People's Representatives, Governor, Municipal/Regency Regional House of People's Representatives, Regent/ Mayor, Village Head or equivalent.

(2) The existence of Regulatory legislation as meant in article (1) is admitted and possess binding legal force as long as it is instructed by the higher regulatory legislation or is formulated based on authority.

A notary is a profession that requires professionalism and hard work to implement their obligation in accordance with the order. ${ }^{15}$ Notary obligations in carrying out their function as mentioned in article 16 paragraph (1) of UUJN are:

a. act honestly, accurately, independently, non-unilaterally, and maintainthe interests of the relevant parties in any legal action;

b. draw up deeds in the form of Minutes of Deed and keep the same as apart of Notarial Protocols;

c. Attach the letter and the document as well as the appearer' fingerprint on the Minutes of Deed;

d. issue executorial deed, Copy, or Excerpt of Deeds based on Minutes of Deed;

e. serve pursuant to this Law, unless there is any reason to refuse them same;

\footnotetext{
${ }^{15}$ Michael Silalahi. (2015). Penegakan Kode Etik Notaris Oleh Dewan Kehormatan Daerah Di Kabupaten Sleman, Tesis, Magister Kenotariatan Fakultas Hukum Universitas Gadjah Mada, Yogyakarta, p. 3.
} 
f. keep secret anything on deeds he/she draws up and any informationhe/she receives to draw up the deeds in accordance with oath of office, unless stipulated otherwise by the law;

g. bind any deeds he/ she draw up in 1 (one) month into a book containing not more than 50 (fifty) deeds, and in case of failure to contain thenumber of the deeds in one book, the deeds can be bound into morethan one book, and record the number of Minutes of Deeds, month, and year of drawing up of the same in the envelope of each book;

h. make a list of deeds of protest against non-payment or non-receipt of securities;

i. make a list of deeds relating to testament according to the sequence of time of drawing up of deeds each month;

j. submit the list of deeds as referred to in the point $\mathrm{i}$ or the list of nihilism relating to testament to the Central Testament Department of which thetasks and responsibilities are in notarial affairs within 5 (five) years in the first week in the following month;

k. record the same in the repertory of the date of submission of the list of testament at each end of the month;

1. have seal/ stamp containing state symbol of the Republic of Indonesia and the space surrounding the same contains name, office, and domicile of the relevant person;

m. read out the deed before the appearer(s) in the presence of at least 2 (two) witnesses or 4 (four) witnesses in drawing up private testamentary disposition, and signed at the same by the appearer(s), witnesses, and Notary Public; and

n. accept the apprenticeship of the prospective Notary Publics.

One of the notary' obligation is act honestly, accurately, independently, non-unilaterally, and maintain the interests of the relevant parties in any legal action. It is important to see that Per.DKP no.1/2017 restricts the deed drawing by the Notary by 20 (twenty) deeds per day. If this restriction is implemented, it will contradict the Notary' obligation to maintain the interests of the relevant parties in any legal action. It may occur if there is a client come before a Notary to ask for a deed but the Notary has reached the limit of deed per day. Therefore, the Notary' rejection may damage the appearer' interest.

Based on the lex superior derogat legi inferiori principle, in which a higher-level rule abrogates a lower one, if there is a conflict between a higher rule and the lower ones, the higher ones shall be prioritized. There is a conflict between Per.DKP No.1/2017 and the regulation in article 16 paragraph (1) point a of UUJN that: "Notary shall act honestly, accurately, independently, non-unilaterally, and maintain the interests of the relevant parties in any legal action." The writer defined phrase "maintain the interest of the relevant parties in any legal action" as an obligation shall be fulfilled by a Notary and shall be able to issue a legal product in accordance with the regulatory legislation in force at the interest of the relevant parties to be written in a deed by the Notary.

Furthermore, one of the notary' obligation in article 16 paragraph (1) point e of UUJN states that " Notary is obligated to serve pursuant to this Law unless there is any reason to refuse the same." What is meant by "refuse the same" is the reason for a notary to be non-unilateral like blood relationship, one of the parties does not hold capability of doing an act or other matters forbidden by the law. Deed restriction regulation as it is mentioned in Per.DKP no.1/2017 according to the writer, cannot be used as a reason to 
refuse the request of the party who appear before a notary in drawing up a deed. If it is used as a reason for notary to refuse to draw up a deed, it is feared that a Notary' credibility and professionalism in providing service towards the appearer decreased.

Based on the matters above, the writer argued that there is no correlation between UUJN and Code of Ethics of Notary or Regulation of Notary Honorary Council of Indonesian Notary Association. It is important to emphasize that in article 8 paragraph (2) of Law no. 12 of 2011 about the Formulation of Regulatory legislation, it is stated that the existence of Regulatory legislation as meant in article (1) is admitted and possess binding legal force as long as it is instructed by the higher regulatory legislation or is formulated based on authority.

In this case, UUJN only instruct Notary to forgather in a Notary Organization known as Indonesian Notary Association, the one and only free and independent profession association for Notary which aim is to enhance the quality of Notary' profession, as it is stated in article 82 of UUJN in which article 83 paragraph (1) of UUJN regulates that Notary Organization determines and enforces Code of Ethics of Notary. Thus, it can be said that one of the supportive factors to enforce the Code of Ethics of Notary is notary' conscience. It means that there shall be notary' awareness to maintain the nobility and the grace of Notary office, implementation optimization of Code of Ethics of Notary may provide a considerable contribution among the notary and organization office profession authority. ${ }^{16}$

Since UUJN does not regulate deed restriction per day specifically, according to the writer, the existence of Per.DKP No.1/2017 cannot be admitted and does not hold legal binding. UUJN does not state the regulation regarding the restriction of deed making. In this case, UUJN only regulate the form and the nature of a deed, it is regulated in article $36-65$ in which the violation against that these regulation cause a deed only have power of evidencing as a deed privately made and it can be a reason for a party suffering a loss to claim for expenses, compensation, and interest to the Notary. A deed privately deeds will not be a problem if what is being listed on such deed is limited to an agreement agreed upon the parties, and such parties admit the truth of the legal action committed within the deed.

If it is reviewed from the phrase "formed based on authority", Per.DKP No.1/2017 is formulated based on article 4 number 16 of Notary COde of Ethic of Indonesian Notary Association which determine that "Notary or other people (as long as the relevant person performs the office of Notary) is prohibited to draw up deeds more than the fairness limit which its amount is determined by the Honorary Council." Article 12 paragraph (2) of articles of association of Indonesian Notary Association also regulates that Honorary council holds duty and authority to create a rule to enforce Notary' Code of Ethics along with the Central Management Board.

In carrying out their authorities, a Notary is externally supervised by the Notary Supervisory Council and is internally supervised by the Notary Honorary Council. ${ }^{17}$ Internal supervision meant, in this case, is supervision in the scope of Indonesian Notary Association which is emphasized on the Notary' ethics supervision through Code of Ethic that has been determined by Indonesian Notary Association. ${ }^{18}$

The Honorary council represents the organization in guiding, supervising, and imposing a sanction in term of the enforcement of Notary Code of Ethics. In this case, the problem is the Notary Honorary Council' authority in inspecting deeds, especially relating to Per.DKP No.1/2017. Notary Honorary Council' authority is mentioned in the articles of association and Code of Ethics of Indonesian

\footnotetext{
${ }^{16}$ Sulhan, et al. (2013). Pelaksanaan Kode Etik Dalam Menjalankan Jabatan Notaris. E-journal, Program Kenotariatan Fakultas Hukum Universitas Hasanuddin Makassar, p.11.

${ }^{17}$ Habib Adjie. (2011). Majelis Pengawas Notaris Sebagai Pejabat Tata Usaha Negara. PT Refika Aditama, Bandung, p. 26.

${ }^{18}$ Heni Kartikosari and Rusdianto Sesung. (2017). Pembatasan Jumlah Pembuatan Akta Notaris Oleh Dewan Kehormatan Pusat Ikatan Notaris Indonesia", Jurnal Al'Adl, Volume IX, Nomor 2, Agustus, p. 249.
} 
Notary Association. Article 12 of Article of Association of Indonesian Notary Association as the result of Indonesian Notary Association Extraordinary Congress in Banten, 29-30 May 2015 states that:

"The Honorary Council possess the duty and the authority to:

- Perform guidance, supervision, development towards member to enforce and respect rights of Notary Code of Ethics;

- Inspect and make a decision on the alleged violation of Code of Ethics of Notary;

- Provide suggestion and idea towards the Supervisory Board and/or Notary Honorary Council on an alleged violation of Code of Ethics of Notary and the office of Notary;

- Carry out coordination, communication, and interaction directly with the members or the parties relevant to the implementation and enforcement of Code of Ethics of Notary;

- Draw up regulation to enforce Code of Ethics of Notary along with the Central Management Board."

The honorary council comprises several members chosen from highly motivated, loyal, wellbehaved, thoughtful Regular Member so he/she may be the role model for the other members and are appointed by the Congress for the same term of office with the term of office of management office. ${ }^{19}$ The honorary council comprises:

1. Central Honorary Council is the Honorary Council in the central level;

2. Regional Honorary Council is the Honorary Council in the provincial 1 level;

3. Regency/Municipal Honorary Council is the Honorary Council in the regency/municipal level;

The authority of Notary Honorary Council is also mentioned in article 6 paragraph (3) of Code of Ethics of Indonesian Notary Association which states that: "Central Honorary Council is authorized to decide and impose sanction for the violation committed by regular member (from active notary) of the organization, towards ethical norms or behavior that disparage the dignity of Notary, or behavior that may decrease the community' trust towards the Notary.

The main duty of Honorary council is to supervise the provision of Notary' Code of Ethic stipulated by the organization involving the organization members' obligation, prohibition, and exception. ${ }^{20}$ In carrying out its duty, Honorary Council may perform an inspection towards the organization members alleged to violate code of Ethic. In its practice, the one who is authorized to perform the inspection is the Notary Supervisory Council, not the Notary Honorary Council. This statement is based on the statement in article 67 and 70 of UUJN, it is stated that:

\section{- Article 67 of UUJN:}

(1) Supervision towards a Notary is done by the Minister

(2) In the supervision as referred to in the paragraph (1), the Minister shall form a Supervisory Council.

(3) The Supervisory Council as referred to in article (2) consist of 9 (nine) members as follows:

a. 3 (three) persons from the Government;

b. 3 (three) persons from Notary Public Organization; and

\footnotetext{
${ }^{19}$ Pasal 12 Angka 3 Perubahan Anggaran Dasar Ikatan Notaris Indonesia Kongres Luar Biasa Ikatan Notaris Indonesia Banten, 29-30 Mei 2015.

${ }^{20}$ Kelik Pramudya dan Ananto Widiatmoko, 2010, Pedoman Etika Profesi Aparat Hukum, Yogyakarta, Pustaka Yustisia,p. 81.
} 
c. 3 (three) experts/ academicians.

(4) In case of absence of the government's elements in one region as referred to in the paragraph (3) point a, membership in the Supervisory Council shall be filled with the other elements appointed by the Minister.

(5) The supervision as referred to in the paragraph (1) shall cover the behavior of Notary Publics and performance of the office of Notary Public.

(6) Provisions on the supervision as referred to in the paragraph (5) shall apply toSubstitute Notary Public and Notary Public Temporary Official.

\section{- Article 70 of UUJN:}

District/ Municipal Supervisory Council is authorized to:

a. hold meetings to investigate the alleged violation of Code of Ethics of Notary Public or violation of performance of office of Notary Public;

b. gradually investigate the Notarial Protocols once in 1(one) year or at any time if considered necessary;

c. give leave permit for up to 6 (six) months;

d. determine Substitute Notary Public by taking into account the recommendation of the relevant Notary Public;

e. determine a place to keep the Notarial Protocols where he/ she has attained the age of 25 (twenty-five) years upon the submission of the Notarial Protocols;

f. appoint a Notary Public to serve as a temporary holder of Notarial Protocols assigned as a state official as referred to in the Article 11 paragraph (4);

g. receive reports from the public on the alleged violation of Code of Ethics of Notary Public or violation of any provisions herein; and

h. make and submit reports as referred to in the points a, b, c, d, e, f, and g toProvincial Supervisory Council.

It is stated in article 70 point b of UUJN that District/ Municipal Supervisory Council is authorized to "gradually investigate the Notarial Protocols once in 1(one) year or at any time if considered necessary" Based on that statement, it is clear that the investigation towards the Notary' deed is done by the Notary Supervisory Council, not Notary Honorary Council. The Notary Supervisory Council comprehends matters regarding the violation on Notary' Deed or Notarial protocol. So, this matter becomes a controversion for the Notary who contradicts against Per.DKP no.1 1/2017.

Supervision on the violation of Code of Ethics of Notary is performed by the Notary Honorary Council, that the dignity of Notary institution may be reflected from the Notary Honorary Council who is 
able to do an action and impose sanction towards the Notary who violates the code of Ethic of Notary. ${ }^{21}$ The enforcement of the Code of Ethics of Indonesian Notary Association as mentioned in article 83 paragraph (1) of UUJN is performed by the Organization of Notary. Based on that regulation, Organization of Notary namely Indonesian Notary Association performs enforcement of Code of Ethics through Central Honorary Council. Based on the articles of association of Indonesian Notary Association, it is stated that Honorary Council is the Organization' instrument to enforce Code of Ethics.

Honorary Council reserve a right to impose a sanction against its guilty member. The imposed sanction is the response to the committed violation based on the regulation in force. ${ }^{22}$ the sanction imposed towards the member who violates Code of Ethics as mentioned in article 6 of Code of Ethics of Notary, can be in the form of:
a. Oral Warning;
b. Written warning;
c. Organization Membership temporary suspension;
d. Organization Membership honorably dismissal;
e. Organization Membership dishonorably dismissal.

Such authority of Honorary Council on the violation of Organization' code of Ethic does not affect directly on the society, or there is no person harmed by the code of Ethics violation, in other words, the authority of Honorary Council is organization' internal. ${ }^{23}$

According to Habib Adjie in an interview with Indonesian Notary Community ${ }^{24}$, Notary may make more than 20 (twenty) deeds in a sequence of legal activity that requires interrelated deed, and/or other deeds, as long as it is accountable which is done in accordance with UUJN, the procedure of notarial' deed making, Notary' Ethics Code (KEN), appropriateness and feasibility as well as other regulatory legislation. Thus, it is clear that Notary is still able to make deed more than 20 (twenty) deeds per day if these deeds is a sequence of legal activity that requires interrelated deed, and/or other deeds, as long as it is accountable which is done in accordance with UUJN, the procedure of notarial' deed making, Notary' code of ethics (KEN), appropriateness and feasibility as well as other regulatory legislation. It is clear that notary may draw up deeds without amount restriction, as long as that deeds drawing meets the requirement meant in article 2 paragraph 2 of Per.DKP no.1/2017.

According to Habib Adjie, the nature of Central Honorary Council is guidance towards the organization member. While, the object of the inspection of Notary Honorary Council is not the notary' deed, but his behavior. In this case, if the notary commits a mistake in drawing a deed, the investigation is conducted by the Notary Supervisory Council. ${ }^{25}$ Drawing a deed is technical and is not ethical or moral matters, so in this case, the writer argues that deed not be the object of Notary Honorary Council investigation.

\footnotetext{
${ }^{21}$ Habib Adjie. (2011). Hukum Notaris Indonesia: Tafsir Tematik Terhadap Undang-Undang Nomor 30 Tahun 2004 tentang Jabatan Notaris, PT Refika Aditama, Bandung, p. 172.

${ }^{22}$ Djidar, Haedar. (2016). The Rivalry Between Notary as A Result of The Determination of Price. Clavia Journal, Volume 16 Number 2 June, p. 5 .

${ }^{23}$ Kelik Pramudya dan Ananto Widiatmoko, (2010), Pedoman Etika Profesi... op.cit., page 82.

${ }^{24} \mathrm{http}: / /$ www.indonesianotarycommunity.com/per-dkp-nomor-12017-tidak-membatasi-kewenangan-notaris/, accessed on Tuesday, 29 May 2018, at 15:39 WIB.

${ }^{25}$ Habib Adjie, Renvoi Nomor: 3.171.XV Agustus 2017, page. 11.
} 


\section{Conclusion}

Limitation on Notarial deed making regulated in Per.DKP No.1/2017 is improper since UUJN does not regulate deed limitation. In addition, notarial deed restriction regulation does not reflect ethical elements, but it regulates a notary public' legal product.

\section{References}

Anke Dwi Saputro. (2008). Jati Diri Notaris Indonesia Dulu. Sekarang dan Di Masa Datang: 100 Tahun Ikatan Notaris Indonesia. Jakarta: PT Gramedia Pustaka.

Djidar, Haedar. (2016). The Rivalry Between Notary as A Result of The Determination of the Price. Clavia Journal. Volume 16 Number 2 June.

Ferry Irawan Febriansyah. (2016). Konsep Pembentukan Peraturan Perundang-undangan di Indonesia. Jurnal Perspektif. Volume XXI No. 3 Edisi September.

Habib Adjie. (2011). Hukum Notaris Indonesia: Tafsir Tematik Terhadap Undang-Undang Nomor 30 Tahun 2004 tentang Jabatan Notaris. Bandung: PT. Refika Aditama.

Aditama. . (2011). Majelis Pengawas Notaris Sebagai Pejabat Tata Usaha Negara. Bandung: PT Refika

Bakti. . (2014). Merajut Pemikiran dalam Dunia Notaris dan PPAT. Bandung: PT Citra Aditya

Hartanti Sulihandari and Nisya Rifiani. (2013). Prinsip-Prinsip Dasar Profesi Notaris. Jakarta: Dunia Cerdas.

Heni Kartikosari and Rusdianto Sesung. (2017). Pembatasan Jumlah Pembuatan Akta Notaris Oleh Dewan Kehormatan Pusat Ikatan Notaris Indonesia. Jurnal Al'Adl.Volume IX Nomor 2 Agustus.

http://ini.id/artikel-content.php?id=1, diakses pada hari Rabu, tanggal 14 Juni 2017 jam 12:15 WIB.

http://medianotaris.com/pembatasan_akta_adalah_ranah_uu_berita477.html, diakses pada hari Rabu, tanggal 14 Juni 2017 jam 12:23 WIB.

http://www.indonesianotarycommunity.com/per-dkp-nomor-12017-tidak-membatasi-kewenangan-not aris/, diakses pada hari Selasa, tanggal 29 Mei 2018, pukul 15:39 WIB.

Kode Etik Ikatan Notaris Indonesia.

Maharani Kumalasari and Moch. Najib Imanullah. (2018). Efektivitas Peraturan Dewan Kehormatan Pusat Ikatan Notaris Indonesia Nomor 1 Tahun 2017 tentang Batas Kewajaran Jumlah Pembuatan Akta Perhari Di Surakarta. Jurnal Repertorium. Volume 5 Nomor 1.

Majalah Renvoi Nomor: 3.171.XV Agustus 2017. 
Michael Silalahi. (2015). Penegakan Kode Etik Notaris Oleh Dewan Kehormatan Daerah Di Kabupaten Sleman. Tesis Magister Kenotariatan Fakultas Hukum Universitas Gadjah Mada Yogyakarta.

Peraturan Dewan Kehormatan Pusat Ikatan Notaris Indonesia Nomor 1 Tahun 2017 tentang Batas Jumlah Kewajaran Pembuatan Akta Perhari.

Peter Mahmud Marzuki. (2014). Penelitian Hukum. Jakarta: Kencana Prenada Media Group.

Undang-Undang Nomor 2 Tahun 2014 Tentang Perubahan Atas Undang-Undang Nomor 30 Tahun 2004 tentang Jabatan Notaris.

Undang-Undang Nomor 12 Tahun 2011 Tentang Pembentukan Peraturan Perundang-Undangan.

Soerjono Soekanto and Sri Mamudji. (2007). Penelitian Hukum Normatif, Suatu Tinjauan Singkat. Jakarta: Raja Grafindo Persada.

Sulhan, et al. (2013). Pelaksanaan Kode Etik Dalam Menjalankan Jabatan Notaris. E-journal. Program Kenotariatan Fakultas Hukum Universitas Hasanuddin Makassar.

\section{Copyrights}

Copyright for this article is retained by the author(s), with first publication rights granted to the journal.

This is an open-access article distributed under the terms and conditions of the Creative Commons Attribution license (http://creativecommons.org/licenses/by/4.0/). 